\title{
Effect of Omega-3 Polyunsaturated Fatty Acid on the Prevention of Atrial Fibrillation after Off-Pump Coronary Artery Bypass Grafting
}

AKM RAKIBUZZAMAN 1 , FAIZUS SAZZAD ${ }^{2}$, MOHAMMAD ARMANE WADUD ${ }^{3}$, MD ABDUL GAFUR ${ }^{4}$, SHAHNAZ ISLAM ${ }^{5}$, ISRAT JAHAN ${ }^{6}$, MD AZIZUL ISLAM KHAN ${ }^{7}$, RAMPADA SARKER ${ }^{7}$

${ }^{1}$ Department of Cardiac Surgery, Combined Military Hospital (CMH), Dhaka, ${ }^{2}$ Centre for Translational Medicine, Department of Cardiac, Thoracic \& Vascular Surgery, National University of Singapore (NUS), Singapore, ${ }^{3}$ Department of Cardiac Surgery Ibrahim Cardiac Hospital \& Research Institute (ICH\&RI), Dhaka, ${ }^{4}$ Department of Cardiac Surgery, National Heart Foundation Hospital \& Research Institute (NHFH\&RI), Dhaka, ${ }^{5}$ Department of Anesthesiology, Bangabandhu Sheikh Mujib Medical University (BSMMU), Dhaka, ${ }^{6}$ Department of Medicine, Bangladesh Institute of Research and Rehabilitation in Diabetes, Endocrine and Metabolic Disorders (BIRDEM), Dhaka, ${ }^{7}$ Department of Cardiac Surgery, National Institute of Cardiovascular Diseases (NICVD), Dhaka.

Address of Correspondence: Faizus Sazzad, Research Fellow/Cardiac Surgeon, Centre for Translational Medicine, Department of Cardiac, Thoracic \& Vascular Surgery, National University of Singapore, Singapore. Email: mfsazzad@gmail.com

\begin{abstract}
Background: Postoperative atrial fibrillation (POAF) often occurs in patients after coronary artery bypass graft surgery (CABG), both conventional and off pump ranges from $11 \%$ to $40 \%$. Although often transient, self-limited, and benign, it may be associated with increased postoperative morbidity. The prevention of POAF has been associated with improved postoperative outcomes in terms of reduced medical treatment, laboratory tests, shorter nursing time, and hospital stay, even when uncomplicated. The present study was conducted to find out the effect of omega polyunsaturated fatty acid on the prevention of POAF after off рuтр CABG
\end{abstract}

Method: This cross-sectional study was conducted in the Department of Cardiac Surgery, National Institute of Cardiovascular Diseases (NICVD), Sher-E-Bangla Nagar, Dhaka, between September 2017 and August 2018. Total 100 patients with sinus rhythm admitted for OPCAB were included in this study, and they were divided into two groups, Group A, 50 patients having omega-3 PUFA in the preoperative and postoperative period up to the fifth postoperative day (POD) and Group B, 50 patients not having omega-3 PUFA in the preoperative and postoperative period up to the fifth $P O D$. Findings were compared between two groups preoperatively, postoperatively, up to 5 days, at discharge, and at one month after discharge.

Results: Postoperative AF was significantly higher in group B in comparison to group $A$ up to $5^{\text {th }} P O D$. AF was present in a few patients during discharge and one month after discharge, but the differences were statistically not significant between groups. Total ICU stay was similar between the two groups, but the postoperative hospital stay was shorter in Group A, and the mean difference was statistically significant.

Conclusion: This study concluded that perioperative oral omega-3 polyunsaturated fatty acid intake reduces the incidence of postoperative atrial fibrillation in patients undergoing off pump coronary artery bypass graft surgery.

Key Words: Omega-3; Polyunsaturated fatty acid (PUFA); Postoperative Atrial fibrillation (POAF); Offpump; Coronary artery bypass grafting (CABG).

University Heart Journal 2022; 18(1): 36-43

Introduction:

Post-Operative Atrial Fibrillation (POAF) is the most common complication that occurs in $25 \%$ after isolated coronary artery bypass grafting (CABG). ${ }^{1-5}$ Although often transient, self-limited, and benign, atrial fibrillation (AF) may be associated with increased postoperative morbidity such as ventricular arrhythmias, myocardial infarction, heart failure, acute kidney injury, stroke, neurocognitive impairment, and infection. ${ }^{3,4}$
The pathophysiological characteristics of POAF after cardiac surgery are multifactorial and has not yet been fully identified ${ }^{1}$ and may be affected by preoperative factors like old age, hypertension, diabetes, obesity, heart failure, ischemic heart disease, chronic obstructive pulmonary disease (COPD); per-operative factors like surgical injury, atrial ischemia, pulmonary vein vent, acute volume changes; postoperative factors like volume overload, increased afterload and hypotension, $\beta$-blockers 
withdrawal, right coronary artery occlusion, reduced left ventricular function and left ventricular hypertrophy are also risk factors as well. ${ }^{6}$ The main common pathway of all these is inflammation and oxidative stress. ${ }^{7-9}$ Surgical trauma to the atria is associated with an increased incidence of POAF, which explains why patients undergoing valvular surgery have the highest risk of developing POAF. ${ }^{1,10,11}$ Some studies suggest that less manipulation of the atria decreases atrial inflammation, and subsequently, AF. ${ }^{1,12}$ POAF after off-pump coronary artery bypass (OPCAB) most often develops between the $2^{\text {nd }}$ to $5^{\text {th }}$ postoperative day with a peak incidence in the $2^{\text {nd }}$ and $3^{\text {rd }}$ postoperative day. ${ }^{13,14}$

The prevention of postoperative atrial fibrillation (POAF) has been associated with improved postoperative outcomes in terms of reduced medical treatment, laboratory tests, shorter nursing time, and hospital stay even when uncomplicated. ${ }^{15-20}$ Considering that POAF is associated with a higher incidence of heart failure, stroke, prolonged hospital stay, and increased costs, it is justifiable to treat it. 1,21

Omega-3 polyunsaturated fatty acid (PUFA) has been widely used for clinical purposes. Clinical studies reported that PUFA is effective in preventing POAF after CABG. ${ }^{22-24}$ PUFA therapy exerts a cardioprotective effect in different experimental and clinical reports, preventing cardiac arrhythmias and sudden death ${ }^{25}$. Several studies have been shown that 2 gm ( 2 capsules) oral omega-3 PUFA supplementation at least five days prior to surgery up to the fifth postoperative day reduces the incidence of POAF and hospital stay significantly. ${ }^{22,24}$

Omega-3 PUFA reduces AF by its anti-inflammatory effect $^{26-29}$ and antiarrhythmic effect. ${ }^{30-34}$ It also reduces by reducing sympathetic outflow ${ }^{35,36}$. It is also associated with reduced AF inducibility, maintenance, and structural remodeling of the heart by activating matrix metalloproteinase-9-mRNA expression and attenuating collagen turnover. ${ }^{37}$ Despite its antiarrhythmic and antiinflammatory characteristics, the use of this drug as a prophylactic agent against the occurrence of postoperative $\mathrm{AF}$ is uncommon, and yet the use of omega3 PUFA as prophylaxis in patients undergoing OPCAB is not routine. The present study was conducted to investigate the effect of omega-3 PUFA in the reduction of post-OPCAB AF among Bangladeshi patients undergone off-pump CABG.

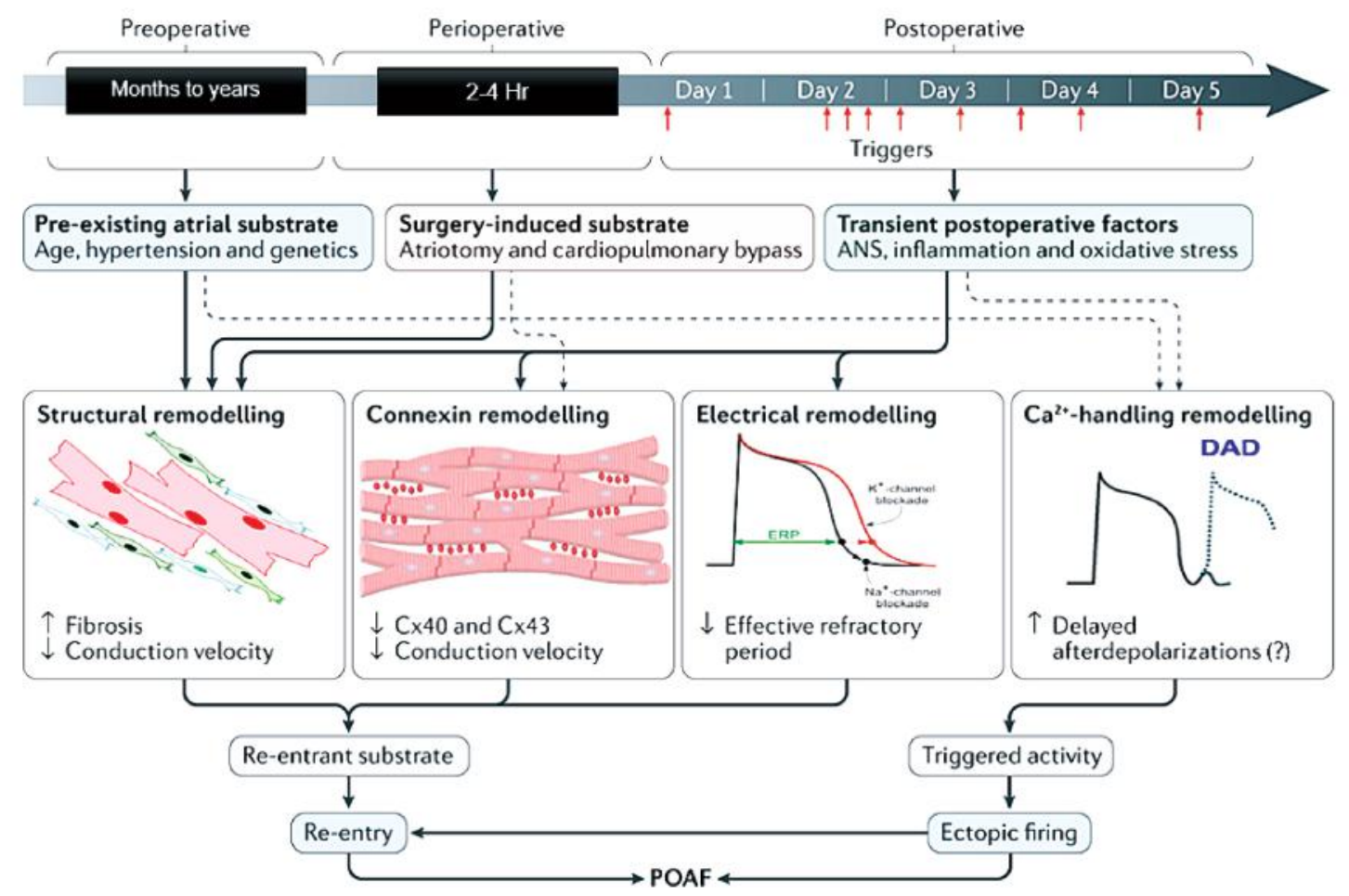

Fig.-1 : Mechanism of perioperative atrial fibrillation (POAF) and its interplay with surgery induced substrates 


\section{Methods and Materials}

This cross-sectional study was conducted in the Department of Cardiac Surgery, National Institute of Cardiovascular Diseases (NICVD), Sher-E-Bangla Nagar, Dhaka, between the periods of $1^{\text {st }}$ September 2017 and $31^{\text {st }}$ August 2018. Purposively selected Patients who were admitted to the department of cardiac surgery at NICVD and planned for OPCAB. Patient with sinus rhythm admitted in the department of cardiac surgery at NICVD for OPCAB. Patients with a history of AF, patients with preoperative AF, patients with a history of MI within six weeks, patients on other antiarrhythmic drugs (Except $\beta$ blockers), left ventricular ejection fraction $\mathrm{d}^{\mathrm{TM}} 35 \%$, combined $\mathrm{CABG}$ and valve and other congenital heart surgery, conversion to on-pump $\mathrm{CABG}$, redo $\mathrm{CABG}$ and urgent or emergency $\mathrm{CABG}$ were excluded from the study. Total 100 patients were included in the study, and they were divided into two groups, Group A, 50 patients with omega-3 PUFA in the preoperative and postoperative period up to $5^{\text {th }} \mathrm{POD}$, and Group B, 50 patients without omega-3 PUFA in the preoperative and postoperative period up to $5^{\text {th }}$ POD. Permission from the institutional review board and informed written consent from all patients were obtained for this study.

The patients were hospitalized at least seven days before surgery. Meticulous history was taken, and detailed clinical examinations were performed, and the presence of preoperative risk factors was recorded in predesigned structured proforma. Demographic data such as age, sex, BMI were recorded. Preoperative ECG, serum potassium using Dimension EXL with LM biochemistry analyzer, and echocardiogram were done in all patients under study. A 12-lead ECG was also done on the morning day of operation, just before the surgery. Omega-3 PUFA was prescribed at a dosage of one tablet $(1 \mathrm{gm})$ twice times daily $(2 \mathrm{gm} /$ day $) 5$ days prior to surgery and up to $5^{\text {th }}$ POD. Per operative occurrence of AF was assessed on OT monitor. After OPCAB surgery, each patient was transferred to the postoperative intensive care unit (ICU), and then on the $3^{\text {rd }}$ postoperative day patient was transferred to a step-down or high dependency unit (HDU). In ICU and HDU, each patient was evaluated by continuous ECG monitor from the operative day, after arrival at ICU up to the fifth postoperative day. Serum potassium was measured daily from the operative day, after arrival at ICU, up to the fifth postoperative day. An episode of atrial fibrillation was counted if it persisted for more than five minutes and was treated accordingly. Total ICU stay and hospital stay after surgery were also recorded. A 12-lead ECG was done, and serum potassium was measured for all patients on the day of hospital discharge and one month after discharge.

\section{Results}

The present study included 100 patients who were undergone $\mathrm{OPCAB}$ during the study period. Half of them were in Group A, preoperatively, and postoperatively on oral omega-3 PUFA, Group A and another half were in Group B, did not on oral omega-3 PUFA preoperatively and post operatively. Among the 50 patients of Group A, the highest number $(78.0 \%)$ of patients were in the age group of 61-70 years followed by 51-60 years age group (20.0\%), and the rest of them were in the 41-50 years age group (2.0\%). Among the Group B patients, the highest number $(60.0 \%)$ were in the age group of $61-70$ years, followed by the age group of 51-60 years (38.0\%), and the rest of them $(2.0 \%)$ were in the age group of $41-50$ years. Mean \pm SD of age among the patients of Group A and Group B was $64.14 \pm 4.44$ and $62.30 \pm 5.29$ years, respectively. Males were predominant in both groups, $82.0 \%$ patients in Group A and $84.0 \%$ patients in Group B. Mean $( \pm \mathrm{SD})$ of BMI of the patients of Group A and Group B were $24.17 \pm 2.27$ and $24.26 \pm 2.16$, respectively. All the patients had some risk factors for coronary artery disease (CAD). In Group A, 70\% were hypertensive, 24\% were diabetic, $6 \%$ patients had heart failure, $82 \%$ patients had a history of MI, and 14\% patients had COPD, and in Group B, 74\% were hypertensive, 36\% were diabetic, $4 \%$ patients had heart failure, $76 \%$ patients had history of MI and $16 \%$ patients had COPD (Table I).

Preoperative 12-lead ECG showed in all patients both the group, seven days prior to surgery and before the operation was in sinus rhythm. The mean $\pm \mathrm{SD}$ of serum potassium were $4.11 \pm 0.51 \mathrm{mEq} / \mathrm{L}$ and $3.93 \pm 0.47 \mathrm{mEq} / \mathrm{L}$ in Group A and Group B, respectively. The mean $\pm \mathrm{SD}$ of LVEF were $58.9 \pm 11.7 \%$ and $59.8 \pm 11.1 \%$ in Group A and Group B, respectively. The mean left atria anteroposterior dimensions were $37.16 \pm 3.82 \mathrm{~mm}$ and $38.36 \pm 3.31 \mathrm{~mm}$ in Group A and Group B, respectively. In Group A, 10.0\% patients had single coronary vessel disease, $24.0 \%$ patients had double coronary vessel disease, and $66.0 \%$ patients had triple vessel disease, and in Group B, 4.0\% patients had single-vessel disease, $36.0 \%$ patients had double vessel disease, and $60.0 \%$ patients had triple vessel disease (Table II).

Mean \pm SD of the number of grafts were $2.38 \pm 0.67$ in

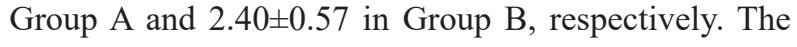
mean \pm SD of operative time in Group A and Group B were $295.3 \pm 24.8$ minutes and $303.0 \pm 2+29.9$ minutes, 
respectively. Regarding the occurrence of AF (OT monitor) per operatively, AF occurred in $4.0 \%$ of patients of Group A and $16 \%$ of patients of Group B (Table 2). On an operative day, after arrival at ICU, the mean $\pm \mathrm{SD}$ of serum potassium was $4.08 \pm 0.44 \mathrm{mEq} / \mathrm{L}$ and $3.93 \pm 0.46 \mathrm{mmol} / \mathrm{L}$ in Group A and Group B, respectively. On $1^{\text {st }}$ POD, the mean \pm SD of serum potassium was $4.05 \pm 0.48 \mathrm{mmol} / \mathrm{L}$ and $3.95 \pm 0.41 \mathrm{mmol} / \mathrm{L}$ in Group A and Group B, respectively. On $2^{\text {nd }} \mathrm{POD}$, the mean $\pm \mathrm{SD}$ of serum potassium were $4.15 \pm 0.46 \mathrm{mmol} / \mathrm{L}$ and $3.98 \pm 0.51 \mathrm{mmol} / \mathrm{L}$ in Group A and Group B, respectively. On $3^{\text {rd }} \mathrm{POD}$, the mean $\pm \mathrm{SD}$ of serum potassium was $3.97 \pm 0.39 \mathrm{mmol} / \mathrm{L}$ and $3.99 \pm 0.50 \mathrm{mmol} /$ L in Group A and Group B, respectively. On $4^{\text {th }}$ POD, the mean \pm SD of serum potassium was $3.94 \pm 0.46 \mathrm{mmol} / \mathrm{L}$ and $4.01 \pm 0.45 \mathrm{mmol} / \mathrm{L}$ in Group A and Group B, respectively. On $5^{\text {th }} \mathrm{POD}$, the mean \pm SD of serum potassium was $4.11 \pm 0.44 \mathrm{mmol} / \mathrm{L}$ and $3.94 \pm 0.48 \mathrm{mmol} / \mathrm{L}$ in Group A and Group B, respectively. At discharge, the mean $\pm \mathrm{SD}$ of serum potassium was $4.15 \pm 0.46 \mathrm{mmol} / \mathrm{L}$ and $4.11 \pm 0.55$ $\mathrm{mmol} / \mathrm{L}$ in Group A and Group B, respectively. After one month of discharge, the mean $\pm \mathrm{SD}$ of serum potassium was $4.08 \pm 0.50 \mathrm{mmol} / \mathrm{L}$ and $4.11 \pm 0.55 \mathrm{mmol} / \mathrm{L}$ in Group A and Group B, respectively.
On an operative day, after arrival at ICU, AF was present in $4.0 \%$ of patients and $18.0 \%$ patients in Group A and Group B, respectively. On $1^{\text {st }}$ POD, AF was present in $8.0 \%$ of patients and $22.0 \%$ patients in Group A and Group $\mathrm{B}$, respectively. On $2^{\text {nd }} \mathrm{POD}, \mathrm{AF}$ was present in $8.0 \%$ of patients and $32.0 \%$ patients in Group A and Group B, respectively. On $3^{\text {rd }} \mathrm{POD}, \mathrm{AF}$ was present in $6.0 \%$ of patients and 30.0\% patients in Group A and Group B, respectively. On $4^{\text {th }} \mathrm{POD}, \mathrm{AF}$ was present in $2.0 \%$ of patients and $20.0 \%$ of patients in Group A and Group B, respectively. On $5^{\text {th }} \mathrm{POD}, \mathrm{AF}$ was present in $2.0 \%$ of patients and $12.0 \%$ patients in Group A and Group B, respectively (Figure-2). AF was present in $4.0 \%$ of patients and $10.0 \%$ patients in Group A and Group B, respectively, on the day of discharge. AF was present in $2.0 \%$ of patients and $6.0 \%$ of patients in Group A and Group B, respectively, after one month of discharge (Table 3). The mean \pm SD duration of ICU stay between Group A and Group B were $5.76 \pm 1.0$ days and $5.46 \pm 0.65$ days, respectively. The mean \pm SD of the duration of postoperative hospital stay in Group A and Group B was 10.48 \pm 1.07 days and $12.04 \pm 1.87$ days, respectively (Table 2 ).

Table-I

Distribution of sociodemographic and comorbidities characteristics of the respondents

\begin{tabular}{|c|c|c|c|}
\hline \multirow[t]{2}{*}{ Variables } & \multicolumn{2}{|c|}{ Groups } & \multirow[t]{2}{*}{ P-value } \\
\hline & Group A & Group B & \\
\hline \multicolumn{4}{|l|}{ Age group f(\%) } \\
\hline $41-50$ & $01(02.0)$ & $01(02.0)$ & \\
\hline $51-60$ & $10(20.0)$ & $19(38.0)$ & \\
\hline $61-70$ & $39(78.0)$ & $30(60.0)$ & \\
\hline $\operatorname{Mean}( \pm \mathrm{SD})$ & $64.14( \pm 4.44)$ & $62.30( \pm 5.29)$ & $0.063^{\#}$ \\
\hline \multicolumn{4}{|l|}{ Gender f $(\%)$} \\
\hline Male & $41(82.0)$ & $42(84.0)$ & $0.790^{*}$ \\
\hline Female & $09(18.0)$ & $08(16.0)$ & \\
\hline \multicolumn{4}{|l|}{ BMI $\left(\mathrm{kg} / \mathrm{m}^{2}\right)$} \\
\hline Underweight $(<18.5)$ & $01(02.0)$ & $01(02.0)$ & \\
\hline Normal (18.5-24.9) & $30(60.0)$ & $34(68.0)$ & \\
\hline Overweight (25.0-29.9) & $19(38.0)$ & $15(30.0)$ & \\
\hline $\operatorname{Mean}( \pm \mathrm{SD})$ & $24.17( \pm 2.27)$ & $24.26( \pm 2.16)$ & $0.845^{\#}$ \\
\hline \multicolumn{4}{|l|}{ Comorbidities f (\%) } \\
\hline Hypertension & $35(70.0)$ & $37(74.0)$ & $0.658^{*}$ \\
\hline Diabetes Mellitus & $12(24.0)$ & $18(36.0)$ & $0.190^{*}$ \\
\hline Heart Failure & $03(06.0)$ & $02(04.0)$ & $0.646^{*}$ \\
\hline History of Myocardial Infarction & $41(82.0)$ & $38(76.0)$ & $0.461^{*}$ \\
\hline COPD & $07(14.0)$ & $08(16.0)$ & $0.779^{*}$ \\
\hline
\end{tabular}

\#P value obtained by student's t-test. *P-value obtained by chi-square test. 
Table-II

Comparison of perioperative investigations and findings between groups

\begin{tabular}{lccc}
\hline Preoperative variables & \multicolumn{2}{c}{ Groups } & P-value \\
\cline { 2 - 3 } & Group A & Group B & \\
\hline Serum K+ (mmol/L) [mean \pm SD] & $4.11 \pm 0.51$ & $3.93 \pm 0.47$ & $0.068^{\#}$ \\
Echocardiography & & & \\
LVEF (\%) [mean $\pm \mathrm{SD}]$ & $58.9 \pm 11.7$ & $59.8 \pm 11.1$ & $0.674^{\#}$ \\
Left atrial A-P dimension (mm)[mean $\pm \mathrm{SD}]$ & $37.16 \pm 3.82$ & $38.36 \pm 3.31$ & $0.096^{\#}$ \\
Coronary Angiogram f(\%) & & & \\
Single Vessel Disease & $05(10.0)$ & $02(4.0)$ & $0.269^{*}$ \\
Double Vessel Disease & $12(24.0)$ & $18(36.0)$ & \\
Triple Vessel Disease & $33(66.0)$ & $30(60.0)$ & \\
Operative variables & & & \\
Total number of grafts (mean $\pm \mathrm{SD})$ & $2.38 \pm 0.67$ & $2.40 \pm 0.57$ & $0.872^{\#}$ \\
Duration of surgery (min) $(\mathrm{mean} \pm \mathrm{SD})$ & $295.3 \pm 24.8$ & $303.0 \pm 2+29.9$ & $0.164^{\#}$ \\
Occurrence of AF (monitor) $\mathrm{f}(\%)$ & $02(04.0)$ & $08(16.0)$ & $0.04^{*}$ \\
Peri-operative variables & & & \\
ICU stay (days) (Mean $\pm \mathrm{SD})$ & $5.76 \pm 1.0$ & $5.46 \pm 0.65$ & $0.078^{\#}$ \\
Post-operative hospital stay(days) $($ Mean $\pm \mathrm{SD})$ & $10.48 \pm 1.07$ & $12.04 \pm 1.87$ & $0.037^{\#}$ \\
\hline \#P value obtained by student's t-test. *P-value obtained by chi-square test. & &
\end{tabular}

Table-III

Comparison of serum potassium level and occurrence of atrial fibrillation (AF) at postoperative day, at discharge, and after one month between two groups

\begin{tabular}{lccc}
\hline Postoperative day & \multicolumn{2}{c}{ Groups } & P-value \\
\cline { 2 - 3 } & Group A & Group B & \\
\hline Serum Potassium mmol/L (Mean \pm SD) & & & $0.100^{\#}$ \\
0 POD & $4.08 \pm 0.44$ & $3.93 \pm 0.46$ & $0.244^{\#}$ \\
$1^{\text {st }}$ POD & $4.05 \pm 0.48$ & $3.95 \pm 0.41$ & $0.081^{\#}$ \\
$2^{\text {nd }}$ POD & $4.15 \pm 0.46$ & $3.98 \pm 0.51$ & $0.827^{\#}$ \\
$3^{\text {rd }}$ POD & $3.97 \pm 0.39$ & $3.99 \pm 0.50$ & $0.470^{\#}$ \\
$4^{\text {th }}$ POD & $3.94 \pm 0.46$ & $4.01 \pm 0.45$ & $0.072^{\#}$ \\
$5^{\text {th }}$ POD & $4.11 \pm 0.44$ & $3.94 \pm 0.48$ & $0.722^{\#}$ \\
At discharge & $4.15 \pm 0.46$ & $4.11 \pm 0.55$ & $0.775^{\#}$ \\
After one month & $4.08 \pm 0.50$ & $4.10 \pm 0.48$ & \\
Occurrence of AF f(\%) & & & $0.025^{*}$ \\
0 POD & $2(4.0)$ & $9(18.0)$ & $0.050^{*}$ \\
$1^{\text {st }}$ POD & $4(8.0)$ & $11(22.0)$ & $0.003^{*}$ \\
$2^{\text {nd }}$ POD & $4(8.0)$ & $16(32.0)$ & $0.002^{*}$ \\
$3^{\text {rd }}$ POD & $3(6.0)$ & $15(30.0)$ & $0.004^{*}$ \\
$4^{\text {th }}$ POD & $1(2.0)$ & $10(20.0)$ & $0.050^{*}$ \\
$5^{\text {th }}$ POD & $1(2.0)$ & $6(12.0)$ & $0.239^{*}$ \\
At discharge & $2(4.0)$ & $5(10.0)$ & $0.307^{*}$ \\
\hline After one month & $1(2.0)$ & $3(6.0)$ & \\
\hline
\end{tabular}

\#P value obtained by student's t-test. *P-value obtained by chi-square test. 


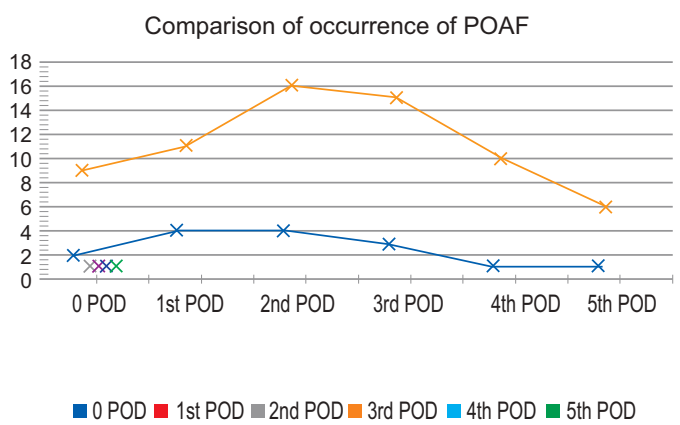

Fig.-2: Occurrence of POAF during the index hospitalization. The occurrence of $A F$ was compared between two groups from the operative day (after arrival at ICU) up to $5^{\text {th }} P O D$ by continuous ECG monitor.

\section{Discussion}

This present study conducted in the Department of Cardiac Surgery, NICVD, included 100 patients undergoing OPCAB. Half of them were in Group A, preoperatively, and postoperatively on oral omega-3 PUFA, Group A and another half were in Group B, did not on oral omega-3 PUFA preoperatively and post operatively. The purpose of this study was to assess the effect of perioperative oral omega-3 PUFA in preventing atrial fibrillation in patients undergone $\mathrm{OPCAB}$.

In the present study majority of patients in Group A and Group B were in the age group of $61-70$ years $78.0 \%$ and $60.0 \%$, respectively. Males were predominant in both groups, which were $82.0 \%$ and $84.0 \%$ in Group A and Group B, respectively. The mean BMI were $24.17 \pm 2.27$ in group A and $24.26 \pm 2.16$ in group B. There is no statistically significant difference in terms of age, sex, BMI between the groups. Studies by Calo et al. (2005) $)^{22}$ and Mariscalco et al. (2010) ${ }^{38}$ also shown similar results.

The risk factors were recorded among the study population. Differences between the two groups for hypertension $(\mathrm{p}=0.658)$, diabetes mellitus $(\mathrm{p}=0.190)$, heart failure $(p=0.646)$, history of MI $(p=0.461)$ and COPD $(p=0.779)$ were not statistically significant. Calo et al. $(2005)^{22}$ and Sorice et al. (2011) ${ }^{24}$ reported similar results in their study. As detected by 12-lead ECG, preoperatively, all the patients in both groups were in sinus rhythm. Preoperative mean \pm SD serum potassium levels were found at $4.11 \pm 0.51 \mathrm{mmol} / \mathrm{L}$ and $3.93 \pm 0.47 \mathrm{mmol} / \mathrm{L}$ $(\mathrm{p}=0.068)$ in Group A and Group B, respectively. The majority of the patients had triple vessel disease, which was $66.0 \%$ and $60.0 \%$ in Group A and Group B, respectively, followed by double vessel disease and single vessel. The differences were not statistically significant.
Villareal et al. $(2004)^{39}$ and a recent review by Sazzad et al $(2021)^{40}$ also found a similar result.

According to the echocardiographic finding, the mean $\pm \mathrm{SD}$ of LVEF in Group A and Group B were $58.9 \pm 11.7 \%$ and $59.8 \pm 11.1 \%$ respectively $(p=0.674)$, and mean \pm SD of left atrial anteroposterior dimension were $37.16 \pm 3.82 \mathrm{~mm}$ and 38.36 $\pm 3.31 \mathrm{~mm}$ in Group A and Group B, respectively $(p=0.096)$. The differences were not statistically significant. Calo et al. (2005) ${ }^{22}$ also found similar results, and they reported the mean \pm SD of LVEF were $55.3 \pm 11.4 \%$ and $56.3 \pm 12.1 \%$ in two groups and mean $\pm \mathrm{SD}$ of left atrial anteroposterior dimension in their study were $39.7 \pm 5.2$ $\mathrm{mm}$ and $38.36 \pm 5.1 \mathrm{~mm}$ in two groups. Mean $\pm \mathrm{SD}$ of the number of grafts were $2.38 \pm 0.67$ and $2.40 \pm 0.57$ in Group A and Group B, respectively $(p=0.872)$. The mean \pm SD of the duration of surgery was $295.3 \pm 24.8$ minutes and $303.0 \pm 2+29.9$ minutes in Group A and Group B, respectively $(p=0.164)$. The differences were not statistically significant. Per operatively, AF was present in $4.0 \%$ patients of Group A and $16.0 \%$ patients of Group $B(p=0.04)$. The occurrence of per operative AF between the groups is statistically significant. The occurrence of AF was compared between two groups from the operative day (after arrival at ICU) up to $5^{\text {th }}$ POD by continuous ECG monitor. The results showed significant differences on operative day, after arrival at ICU $(p=0.025), 1^{\text {st }} \mathrm{POD}$ $(p=0.050), 2^{\text {nd }} \operatorname{POD}(p=0.003), 3^{\text {rd }} \operatorname{POD}(p=0.002)$, $4^{\text {th }}$ POD $(p=0.004)$ and $5^{\text {th }}$ POD $(p=0.050)$. The occurrence of $\mathrm{AF}$ was also compared between two groups on the day of discharge from the hospital and after one month of discharge by 12-lead ECG. But the differences were not statistically significant at discharge $(p=0.239)$ and one month after discharge $(\mathrm{p}=0.307)$. Mariscalco et al. $(2010)^{38}$ also found similar results.

The mean $\pm \mathrm{SD}$ of serum potassium level was compared between two groups from the operative day (after arrival at ICU) up to $5^{\text {th }}$ POD and there were no significant differences on operative day, after arrival at ICU $(p=$ $0.100), 1^{\text {st }} P O D(p=0.244)$, and $2^{\text {nd }} P O D(p=0.081), 3^{\text {rd }}$ POD $(p=0.827), 4^{\text {th }}$ POD $(\mathrm{p}=0.470), 5^{\text {th }}$ POD $(\mathrm{p}=$ $0.072)$, at discharge $(p=0.722)$ and one month after discharge $(\mathrm{p}=0.775)$. The mean $\pm \mathrm{SD}$ of total ICU stay was $5.76 \pm 1.0$ days and $5.46 \pm 0.65$ days $(p=0.078)$ in Group A and Group B, respectively. The difference was not statistically significant between the two groups. The mean \pm SD of hospital stay after surgery was $10.48 \pm 1.07$ days and $12.04 \pm 1.87$ days $(p=0.037)$ in Group A and Group B, respectively. The difference was statistically significant between the two groups. Total ICU stay was 
similar between the two groups, but the postoperative hospital stay was shorter in Group A than in Group B, and the difference is statistically significant.

Calo et al. (2005), ${ }^{22}$ Mariscalco et al. (2010), ${ }^{38}$ and Langlois et al. (2017) ${ }^{41}$ in their study reported similar results of ICU to stay and hospital stay between two groups. Costanzo et al. (2013), ${ }^{42}$ in their meta-analysis of 8 RCTs and 2,687 patients, reported that preoperative supplementation of n-3 PUFA significantly reduces the incidence of POAF by $16 \%$ in patients undergoing cardiac surgery, and they also reported that this effect was more pronounced with a $34 \%$ reduction in POAF (OR, 0.66; $95 \%$ CI, 0.50-0.87; $\mathrm{p}=0.003$ ) in patients undergoing CABG. But another metaanalysis by Mariani et al. $(2013)^{43}$, however, reported no significant benefit (OR $0.86 ; 95 \%$ CI, 0.71 to 1.04 ) with supplementing n-3 PUFA in preventing POAF. Additionally, the occurrence of POAF was similar to Sazzad et al (2018) ${ }^{44}$ and Salekin et al (2019). ${ }^{45}$ Multicenter randomized control trials with a larger sample size among the Bangladeshi population undergone $\mathrm{CABG}$ can further generate knowledge regarding this issue that benefits the patient's outcome after cardiac surgery.

\section{Conclusion}

This study concluded that perioperative oral omega-3 polyunsaturated fatty acid intake reduces the incidence of postoperative atrial fibrillation in patients undergoing off pump coronary artery bypass graft surgery.

\section{References}

1. Alqahtani AAR. Atrial Fibrillation Post Cardiac Surgery Trends Toward Management. Heart Views 2010;11(2):57-63.

2. Attaran S, Shaw M, Bond L, Pullan MD, Fabri BM. Atrial fibrillation postcardiac surgery: a common but morbid complication. Interactive CardioVascular and Thoracic Surgery 2011;12(5):772-77.

3. Helgadottir S, Sigurdsson MI, Ingvarsdottir IL et al. Atrial fibrillation following cardiac surgery: risk analysis and long-term survival. J Cardiothorac Surg 2012;7:87. https://doi.org/10.1186/ 1749-8090-7-87.

4. Greenberg JW, Timothy S. Lancaster, Richard B. Schuessler, Spencer J. Melby Postoperative atrial fibrillation following cardiac surgery: a persistent complication. European Journal of CardioThoracic Surgery 2017;52(4):665-72.

5. Burrage PS, Low YH, Campbell NG, et al. New-Onset Atrial Fibrillation in Adult Patients After Cardiac Surgery. Curr Anesthesiol Rep 2019;9:174-93.

6. Budeus M, Hennersdorf M, Perings S, Rohlen S, Schnitzler S, Felix O, Reimert K, Feindt P, Gams E, Lehmann N, Wieneke H, Sack S, Erbel R. Amiodarone prophylaxis for atrial fibrillation of high-risk patients after coronary bypass grafting: a prospective, double-blinded, placebo-controlled, randomized study. European Heart Journal 2006; 27(13):1584-91.

7. Gaudino M, Andreotti F, Zamparelli R, Castelnuovo A, Nasso G, Burzotta F, Iacoviello L, Donati MB, Schiavello R, Maseri A, Passati G. The -174G/C interleukin-6 level and postoperative atrial fibrillation: is atrial fibrillation an inflammatory complication? Circulation 2003;108(10):195-99.

8. Echahidi N, Pibarot P, O'Hara G, Mathieu P. Mechanism, prevention and treatment of atrial fibrillation after cardiac surgery. Journal of the American College of Cardiology 2008;51(8): 793-801.

9. Elahi MM, Flatman S, Matata BM. Tracing the origins of postoperative atrial fibrillation: the concept of oxidative stressmediated myocardial injury phenomenon. European Journal of Preventive Cardiology 2008;15(6):735-41.

10. Creswell LL, Schuessler RB, Rosenbloom M, Cox JL. Hazards of postoperative atrial arrhythmias. Ann Thorac Surg. 1993;56: $539-49$

11. Mathew JP, Parks R, Savino JS, Friedman AS, Koch C, Mangano DT, et al. Atrial fibrillation following coronary artery bypass graft surgery: predictors, outcomes, and resource utilization. Multicenter Study of Perioperative Ischemia Research Group. JAMA. 1996;276:300-306.

12. Stamou SC, Dangas G, Hill PC, Pfister AJ, Dullum MK, Boyce $\mathrm{SW}$, et al. Atrial fibrillation after beating heart surgery. Am J Cardiol. 2000;86:64-67.

13. Ommen SR, Odell JA, Stanton MS. Atrial arrhythmias after cardiothoracic surgery. The New England Journal of Medicine 1997;336(1):1429-34.

14. Cagli K, Gol MK, Keles T, Sener E, Yildiz U, Uncu H, Tasdemir O, Bayazit K. Risk factors associated with development of atrial fibrillation early after coronary artery bypass grafting. The American Journal of Cardiologist 2000;85(10):1259-61.

15. Turagam MK, Downey F, Kress D, Sra J, Jamil Tajik J, Arshad Jahangir A. Pharmacological strategies for prevention of postoperative atrial fibrillation. Expert Rev Clin Pharmacol 2015; 8(2): 233-50.

16. Mathew JP, Fontes ML, Tudor IC, et al. A multicenter risk index for atrial fibrillation after cardiac surgery. JAMA 2004;291(14):1720-29.

17. Maniscalco G, Engstrom KG. Postoperative atrial fibrillation is associated with late mortality after coronary surgery, but not after valvular surgery. Ann Thorac Surg 2009;88(6):1871-76.

18. El-Chami MF, Kilgo P, Thourani V, et al. New-onset atrial fibrillation predicts long-term mortality after coronary artery bypass graft. J Am Coll Cardiol 2010;55(13):1370-76.

19. Ohlsson A, Fengsrud E, Bodin L, Englund A. Postoperative atrial fibrillation in patients undergoing aortocoronary bypass surgery carries an eightfold risk of future atrial fibrillation and a doubled cardiovascular mortality. Eur J Cardiothorac Surg 2010;37(6):1353-59.

20. Zaman AG, Archbold RA, Helft G, Paul EA, Curzen NP, Mills PG. Atrial fibrillation after coronary artery bypass surgery: a model for preoperative risk stratification. Circulation 2000;101(3): 1403-04. 
21. January CT, Wann LS, Alpert JS, Calkins H, Cigarroa JE, Cleveland JC, Jr, Conti JB, Ellinor PT, Ezekowitz MD, Field ME, Murray KT, Sacco RL, Stevenson WG, Tchou PJ, Tracy CM, Yancy CW; ACC/AHA Task Force Members. 2014 AHA/ACC/HRS guideline for the management of patients with atrial fibrillation: a report of the American College of Cardiology/American Heart Association Task Force on practice guidelines and the Heart Rhythm Society. Circulation. 2014;130:e199-e267.

22. Calo L, Bianconi L, Colivicchi F, Lamberti F, Loricchio ML, Ruvo E, Meo A, Pandozi C, Staibano M, Santini M. 2005. N-3 fatty acids for the prevention of atrial fibrillation after coronary artery bypass surgery: a randomized, controlled trial. Journal of American College of Cardiology 2005; 45(10):1723-28.

23. Heidt MC, Vician M, Stracke SKH, Stadlbauer T, Grebe MT, Boening A, Vogt PR, Erdogan A. 2009. Beneficial effects of intravenously administered N-3 fatty acids for the prevention of atrial fibrillation after coronary artery bypass surgery: a prospective randomized study. The Thoracic and Cardiovascular Surgeon 2009;57(5):276-80.

24. Sorice M, Tritto FP, Sordelli C, Gregorio R, Piazza L. 2011. N-3 polyunsaturated fatty acid reduces postoperative atrial fibrillation incidences in patients undergoing "on-pump" coronary artery bypass graft surgery. Monaldi Archives for Chest Disease 2011; 76(2):93-98.

25. Mozaffarian D, Psaty BM, Rimm EB, Lemaitre RN, Burke G, Lyles ME, Lefkowitz Z, Siscovick DS. Fish intake \& risk of incident atrial fibrillation. Circulation 2004;110(4):368-73.

26. Kalman JM, Munawar M, Howes LG, Louis WJ, Buxton BF, Gutteridge G, Tonkin AM. 1995. Atrial fibrillation after coronary artery bypass grafting is associated with sympathetic activation. The Annals of Thoracic Surgery 1995;60(6):1709-15.

27. Benjamin EJ, Wolf PA, D’Agostino RB, Silbershatz H, Kannel WB, Levy D. 1998. Impact of atrial fibrillation on the risk of death: the Framingham Heart Study. Circulation 1998;98(10): 946-52.

28. Lee TH, Hoover RL, William JD, Sperling RI, Ravalese J, Spur BW, Robinson DR, Corey EJ, Lewis RA, Austen KF. Effect of dietary enrichment with eicosapentaenoic and docosahexaenoic acids on in vitro neutrophil and monocyte leukotriene generation and neutrophil function. The New England Journal of Medicine 1985;312(19):1217-24.

29. Miles EA, Wallace FA, Calder PC. 2000. Dietary fish oil reduces intercellular adhesion molecule and scavenger receptor expression on murine macrophage. Atherosclerosis 2000;152(1):43-50.

30. Mclennan P, Bridle TM, Physiol HNC, Albeywardena MY, Charnock J. 1992. Dietary lipid modulation of ventricular fibrillation threshold in the marmoset monkey. American Heart Journal 1992;123(6):1555-61.

31. Kang J and Leaf A. Prevention and treatment of arrhythmia induced by lysophosphatidylcholine and acylcarnitine in neonatal rat cardiac myocyte by free omega-3 polyunsaturated fatty acid. European Journal of Pharmacology 1996;297(7): 97-106.

32. Leaf A. The electrophysiological basis for the antiarrhythmic action of polyunsaturated fatty acid. European Heart Journal Supplements 2001;3(1):98-105.
33. Xiao YF, Wright SN, Wang GK, Morgan JP, Leaf A. 1998. Fatty acid suppress voltage-gated $\mathrm{Na}^{+}$current in HEK293t cells transfected with the á- subunit of the human cardiac $\mathrm{Na}^{+}$channel. Proceeding of The National Academy of Science of The United States of America 1998;95(5):2680-85.

34. Kang XJ, Xiao Y, Leaf A. Free long-chain fatty acids reduce membrane electrical excitability in neonatal rat cardiac myocytes. Proceeding of National Academy of Science of the United States of America 1995;92(9):3997-4001.

35. Singer P, Jaeger W, Writh M, Voigt S, Naumann E, Zimontkowski S, Hajdu I, Goedicke W. 1983. Lipid and blood pressure-lowering effect of mackerel diet in man. Atherosclerosis 1983;49(1): 99-108.

36. Hashimoto M, Shinozuka K, Gamoh S, Tanabe Y, Hossain M, Kwon Y, Hata N, Misawa Y, Kunitomo M, Masumura S. 1999. The hypotensive effect of docosahexaenoic acid is associated with the enhanced release of ATP from the caudal artery of aged rats. The Journal of Nutrition 1999;129(1):70-76.

37. Laurent G, Moe G, Hu X, Holub B, Leong-poi H, Trogadis J, Connelly K, Courtman D, Strauss BH, Dorian P. Long-chain n-3 polyunsaturated fatty acids reduce atrial vulnerability in a novel canine pacing model. Cardiovascular Research 2008;77(1): 89-97.

38. Mariscalco G, Braga SS, Banach M, Borsani P, Bruno VD, Napoleone M, Vitale C, Piffaretti G, Pedretti RFE, Sala A. 2010. Preoperative n-3 polyunsaturated fatty acids are associated with a decrease in the incidence of early atrial fibrillation following cardiac surgery. Angiology 2010;61(7):643-50.

39. Villareal RP, Hariharan R, Liu BC, Kar B, Lee VV, Elayda M, Lopez A, Rasekh A, Wilson JM, Massumi A. 2004. Postoperative atrial fibrillation and mortality after coronary artery bypass surgery. Journal of the American College of Cardiology 2004;43(5): $742-48$.

40. Sazzad, F., Ler, A. A. L., Ganesh, G., Kung, M., \& Kofidis, T. (2021). Systematic Review and Pooled Meta-analysis of the Current Status of Coronary Revascularization Surgery in Bangladesh. Bangladesh Heart Journal, 35(2), 87-99.

41. Langlois PL, Hardy G, Manzanares W. 2017. Omega-3 polyunsaturated fatty acids in cardiac surgery patients: An updated systematic review and meta-analysis. Clinical Nutrition 2017;36(3):737-46.

42. Costanzo S, di Niro V, Di Castelnuovo A, et al. Prevention of postoperative atrial fibrillation in open-heart surgery patients by preoperative supplementation of $\mathrm{n}-3$ polyunsaturated fatty acids: an updated meta-analysis. J Thorac Cardiovasc Surg 2013; 146(4):906-11.

43. Mariani J, Doval HC, Nul D, et al. N-3 polyunsaturated fatty acids to prevent atrial fibrillation: updated systematic review and metaanalysis of randomized controlled trials. J Am Heart Assoc 2013; 2(1): 005033.

44. Sazzad, M. F., Chanda, P. K., \& Ahmed, F. (2018). The Effects of Perioperative Intra-aortic Balloon Counter Pulsation on Left Ventricular Function in Patients Undergoing Coronary Revascularization Surgery. Bangladesh Heart Journal, 32(2), 94-99.

45. Salekin, M. S., Sazzad, M. F., Nahian, S. A., Mohammad Musa, S. A., Alam, M. R., Choudhury, D. I. R., \& Adhikary, A. B. (2019). Short Term Outcome of Off Pump Coronary Artery Bypass Grafting in Patients with Low Ejection Fraction. University Heart Journal, 14(2), 53-61. 